\title{
EFEKTIVITAS ORGANISASI PELAYANAN KEPERAWATAN BERDASARKAN KOMUNIKASI, PENGAMBILAN KEPUTUSAN, SOSIALISASI KARIR, DAN JENJANG KARIR
}

\author{
Ridwan $^{1,2 *}$, Dewi Irawaty ${ }^{3}$, Sutanto P. Hastono ${ }^{4}$ \\ 1. Akademik Keperawatan Yarsi Pontianak, Kalimantan Barat 78232, Indonesia \\ 2. Program Studi Magister Fakultas Ilmu Keperawatan Universitas Indonesia, Depok 16424, Indonesia \\ 3. Fakultas Ilmu Keperawatan Universitas Indonesia, Depok 16424, Indonesia \\ 4. Fakultas Kesehatan Masyarakat Universitas Indonesia, Depok 16424, Indonesia
}

*Email: iwannurse@yahoo.com

\begin{abstract}
Abstrak
Tujuan penelitian ini adalah mengetahui hubungan proses organisasi (komunikasi; pengambilan keputusan; sosialisasi karir dan jenjang karir) dengan efektivitas organisasi dalam pelayanan keperawatan pada struktur organisasi dengan pendekatan sentralisasi dan desentralisasi di Rumah Sakit. Kuesioner disebarkan kepada 104 responden yang merupakan total sampel, yaitu perawat pelaksana yang dipilih berdasarkan kriteria inklusi. Hubungan antara variabel independen dan dependen serta uji beda untuk setiap variabel pada pendekatan sentralisasi dan desentralisasi diuji menggunakan analisis Chi-square. Hasil analisis multivariat menggunakan uji regresi logistik prediksi menunjukkan adanya hubungan yang signifikan antara proses organisasi dengan efektivitas organisasi, baik pada pendekatan sentralisasi maupun desentralisasi $(p<0,05, \alpha=0,05)$. Pada aspek efektivitas, hasil penelitian menunjukkan hasil $31,7 \%$ pada pendekatan sentralisasi dan $42,3 \%$ pada pendekatan desetnralisasi. Untuk itu, pihak manajemen rumah sakit perlu mengupayakan berbagai strategi manajemen keperawatan untuk meningkatkan efektivitas dan mutu pelayanan keperawatan di rumah sakit.
\end{abstract}

Kata kunci: proses organisasi, efektivitas organisasi, sentralisasi, desentralisasi.

\begin{abstract}
The objective of this research is to find out the relationship within organizational process (communication, decision making, career socialization, and career opportunity) and the effectiveness of the organization in giving nursing care using centralization approach and decentralization approach in Hospital. The questioners were given to a total sample of 104 respondents; they were associate nurses who were chosen using inclusion criteria. The relationship between independent and dependent variable, and the test to differentiate each variable in both centralization and decentralization approach were tested using chi-square analysis. The multivariate analysis using logistic regression prediction test showed that there was a significant relationship between organizational process and the effectiveness of the organization, both in centralization and decentralization approach $(p<0,05 ; \alpha=0,05)$. Moreover this study also showed that the effectiveness in centralization approach was $31.7 \%$, whilst in the decentralization approach was $42.3 \%$. It is recommended that the hospital's management should apply several strategies of management in nursing in order to increase the effectiveness and the quality of nursing services in hospital.
\end{abstract}

Key words: Organizational process and effectiveness, centralization and decentralization

\section{Pendahuluan}

Pada tahun 2005 telah terjadi perubahan struktur organisasi di salah satu Rumah Sakit Umum Daerah (RSUD) Pontianak. Bidang keperawatan yang pada struktur lama mengelola pelayanan keperawatan ditiadakan, dimerger dengan bidang pelayanan rumah sakit. Dengan ditiadakannya bidang keperawatan dan diberdayakannya bidang pelayanan dapat diartikan bahwa struktur organisasi telah mengalami perubahan dari struktur yang bersifat sentralisasi menjadi struktur yang bersifat desentralisasi. Perubahan ini berdampak terhadap kinerja staf pelayanan keperawatan sebagai sebuah organisasi.
Struktur organisasi tanpa diragukan berhubungan dengan pencapaian efektivitas organisasi (Gibson, Ivancevich \& Donelly, 1996). Hal ini didukung oleh Kushner dan Poole (1996, dalam Schmid, 2002), menyatakan terdapat korelasi positif antara struktur organisasi dan efektifitas organisasi. Dengan demikian struktur organisasi yang berubah dapat berdampak pada efektivitas organisasi. Meski terjadi perubahan jenis struktur organisasi yang digunakan, kriteria efektivitas organisasi dapat diidentifikasi dengan beberapa persyaratan minimal, yaitu struktur organisasi harus ada batasan jelas, sedikit mungkin tingkat manajemen dan sependek mungkin rantai komando, serta harus meningkatkan komunikasi. 
Disamping itu, menfasilitasi pengambilan keputusan yang menghasilkan kinerja pekerjaan yang terbaik (Marquis dan Huston, 2006).

Organisasi yang tidak ada departemen keperawatan, para perawat harus melakukan tindakan tambahan untuk memastikan bahwa mereka dan para koleganya menjalankan standar keperawatan dan memastikan mutu kinerja (Beyers, 1999). Hal ini terjadi karena mengingat pentingnya struktur suatu departemen keperawatan dalam mendukung tujuan organisasi, falsafah dan tujuan keperawatan serta menunjukkan bagaimana setiap posisi keperawatan berhubungan dengan departemen lain di dalam institusi (Gillies, 1994).

Dalam sebuah organisasi dengan sentralisasi yang tinggi, penguasaan wewenang dan sebagian besar keputusan diambil oleh eksekutif di daerah puncak (Gillies, 1994; Gibson, Ivancevich dan Donelly, 1997). Pada pendekatan desentralisasi otoritas yang diberikan dekat pada sumber pelaksanaan, sehingga membantu memperlancar pekerjaan (Winardi, 2004). Pada organisasi yang tersentralisasi, pengambilan keputusan dilakukan oleh beberapa manajer tingkat atas, sedangkan pada organisasi yang terdesentralisasi, pengambilan keputusan tentang suatu masalah dapat diselesaikan pada tingkat dimana masalah itu terjadi dan mempunyai potensi untuk meningkatkan kualitas hasil asuhan dan meningkatkan efektivitas organisasi (Hagenstad, Weis \& Brophy, 2000; Krairiksh \& Anthony, 2001 dalam Marquis \& Huston, 2006).

Proses organisasi melibatkan tiga proses perilaku yang berkontribusi dalam kinerja dan efektivitas organisasi, yaitu: komunikasi, pengambilan keputusan dan sosialisasi karir serta pengembangan karir (Gibson, Ivancevich \& Donelly, 1996). Komunikasi sangat penting bagi para manajer dan bagi pekerjaan mereka, karena kekuasaan, kepemimpinan dan pengambilan keputusan tergantung pada proses komunikasi baik eksplisit maupun implisit (Hall, 2002). Komunikasi berfungsi untuk mengendalikan perilaku anggotanya, memelihara motivasi untuk meningkatkan kinerja (Robbins, 2002).

Tujuan penelitian adalah untuk mengetahui perbedaan hubungan proses organisasi (komunikasi, pengambilan keputusan, sosialisasi karir dan jenjang karir) dengan efektivitas organisasi dalam pengelolaan keperawatan pada struktur organisasi dengan pendekatan sentralisasi dan desentralisasi yang dalam hal ini akan dikaji dari sudut pandang atau perspektif perawat pelaksana.

\section{Metode}

Penelitian ini menggunakan disain deskriptif komparatif dengan cara mencari hubungan antar variabel independen, yaitu proses organisasi (komunikasi; pengambilan keputusan; sosialisasi karir dan jenjang karir) dengan variabel dependen, yaitu efektivitas organisasi pada pendekatan sentralisasi dan desentralisasi, kemudian membandingkannya. Penelitian dilakukan di salah satu RSUD Pontianak dengan menyebarkan kuesioner kepada 104 perawat pelaksana yang merupakan total sampel. Kriteria responden yaitu perawat pelaksana dengan pendidikan minimal DIII dan masa kerja 3 tahun atau lebih. Pengumpulan data dilakukan pada 23 - 29 Mei 2007.

Analisis data yang digunakan dalam penelitian ini adalah univariat bivariat dan multivariat. Uji hubungan antara variabel independen dan dependen serta uji beda untuk setiap variabel pada pendekatan sentralisasi dan desentralisasi menggunakan analisis Chi-square, sedangkan pada analisis multivariat dilakukan dengan uji regresi logistik model prediksi dengan tingkat kepercayaan (CI) $95 \%$ atau $\alpha$ sebesar 0,05 .

\section{Hasil}

Tabel 1. Distribusi Proses Organisasi pada Pendekatan Sentralisasi dan Desentralisasi

\begin{tabular}{|c|c|c|c|c|}
\hline \multirow{2}{*}{$\begin{array}{c}\text { Proses } \\
\text { Organisasi }\end{array}$} & \multicolumn{2}{|c|}{ Sentralisasi } & \multicolumn{2}{|c|}{ Desen tralisasi } \\
\hline & $\mathbf{N}$ & $\%$ & n & $\%$ \\
\hline Komunikasi : & & & & \\
\hline - Efektif & 45 & 43,3 & 54 & 51,9 \\
\hline - Kurang Efektif & 59 & 56,7 & 50 & 48,1 \\
\hline Jumlah & 104 & 100 & 104 & 100 \\
\hline Pengambilan & & & & \\
\hline Keputusan: & 22 & 21,2 & 42 & 40,4 \\
\hline - Tepat & 82 & 78,8 & 62 & 59,6 \\
\hline $\begin{array}{c}\text { - Kurang Tepat } \\
\text { Jumlah }\end{array}$ & 104 & 100 & 104 & 100 \\
\hline $\begin{array}{l}\text { Sosialisasi Karir } \\
\text { dan Jenjang Karir }\end{array}$ & 12 & 11,5 & 26 & 25 \\
\hline - Jelas & 92 & 88,5 & 78 & 75 \\
\hline $\begin{array}{c}\text { - Kurang Jelas } \\
\text { Jumlah } \\
\end{array}$ & 104 & 100 & 104 & 100 \\
\hline
\end{tabular}


Hasil penelitian menunjukkan struktur organisasi sentralisasi dengan $56,7 \%$ responden mengatakan komunikasi masih kurang efektif, 78,8\% responden mengatakan pengambilan keputusan yang dilakukan oleh pihak manajemen RS masih kurang tepat dan $88,5 \%$ responden yang mengatakan sosialisasi karir dan jenjang karir masih kurang jelas (lihat tabel 1). Sedangkan pada struktur organisasi desentralisasi menunjukkan sebanyak $51,9 \%$ responden mengatakan bahwa komunikasi sudah berjalan efektif, sebanyak 59,6\% n responden beranggapan bahwa pengambilan keputusan yang dilakukan oleh pihak manajemen RS masih kurang tepat, dan sebanyak $75 \%$ responden mengatakan bahwa sosialisasi karir dan jenjang karir masih kurang jelas.

Hasil penelitian menunjukkan bahwa efektivitas organisasi pada pendekatan sentralisasi yaitu hanya ada sebanyak $31,7 \%$ responden yang mengatakan bahwa organisasi efektif, sedangkan sebanyak $68,3 \%$ responden mengatakan bahwa RS masih kurang efektif. Sedangkan pada pendekatan desentralisasi menunjukkan sebanyak 42,3\% responden mengatakan RS sudah efektif, namun masih ada sebanyak 57,7\% mengatakan bahwa RS masih kurang efektif(lihat tabel 2).

Pada pendekatan sentralisasi ada hubungan yang signifikan antara komunikasi dengan efektivitas organisasi $(p=0,000, \alpha=0,05)$, pengambilan keputusan dengan efektivitas organisasi $(\mathrm{p}=0,020$, $\alpha=0,05)$, serta sosialisasi karir dan jenjang karir dengan efektivitas organisasi ( $\mathrm{p}=0,000, \alpha=0,05)$ (lihat tabel 3).
Tabel 2. Distribusi Efektivitas Organisasi pada Pendekatan Sentralisasi dan Desentralisasi

\begin{tabular}{lcccc}
\hline Efektivitas & \multicolumn{2}{c}{ Sentralisasi } & \multicolumn{2}{c}{ Desentralisasi } \\
Organisasi & N & \% & N & \% \\
\hline Efektif & 33 & 31,7 & 44 & 42,3 \\
Kurang Efektif & 71 & 68,3 & 60 & 57,7 \\
$\quad$ Jumlah & 104 & 100 & 104 & 100 \\
\hline
\end{tabular}

Pada pendekatan desentralisasi, ada hubungan yang signifikan antara komunikasi dengan efektivitas organisasi $(p=0,000, \alpha=0,05)$, pengambilan keputusan dengan efektivitas organisasi $(\mathrm{p}=0,000$, $\alpha=0,05)$, serta sosialisasi karir dan jenjang karir dengan efektivitas organisasi ( $\mathrm{p}=0,000, \alpha=0,05)$ (lihat tabel4). Hasil analisis juga menunjukkan ada hubungan yang signifikan antara sosialisasi karir dan jenjang karir dengan efektivitas organisasi pada pendekatan desentralisasi $(\mathrm{OR}=7,500)$. Pada pendekatan desentralisasi, sosialisasi karir dan jenjang karir yang jelas mempunyai peluang 7,5 kali untuk menyebabkan efektivitas organisasi dibanding sosialisasi karir dan jenjang karir yang kurang jelas.

Tidak ada perbedaan proporsi komunikasi antara struktur organisasi pada pendekatan sentralisasi dengan pendekatan desentralisasi $(p=0,267, \alpha=$ 0,05 ) (lihat tabel 5). Namun, ada perbedaan proporsi pengambilan keputusan antara struktur organisasi pada pendekatan sentralisasi dengan desentralisasi. Struktur organisasi dengan pendekatan desentralisasi berpeluang 2,52 kali untuk menghasilkan pengambilan keputusan yang tepat dalam organisasi dibanding struktur dengan pendekatan sentralisasi $(p=0,004, O R=2,525, \alpha=0,05)$.

Tabel 3. Hubungan Proses Organisasi dengan Efektivitas Organisasi pada Pendekatan Sentralisasi

\begin{tabular}{|c|c|c|c|c|c|c|c|c|}
\hline \multirow{3}{*}{ Proses Organisasi } & \multicolumn{4}{|c|}{ Efektivitas Organisasi } & \multirow{2}{*}{\multicolumn{2}{|c|}{ Total }} & \multirow{3}{*}{$\begin{array}{c}\text { OR } \\
95 \% \mathrm{CI}\end{array}$} & \multirow{3}{*}{$\mathbf{p}$} \\
\hline & \multicolumn{2}{|c|}{ Efektif } & \multicolumn{2}{|c|}{ Kurang Efektif } & & & & \\
\hline & $\mathbf{n}$ & $\%$ & $\mathbf{n}$ & $\%$ & $\mathbf{N}$ & $\%$ & & \\
\hline Komunikasi : & & & & & & & & \\
\hline - Efektif & 8 & 13,6 & 51 & 86,4 & 59 & 100 & 7,969 & \\
\hline - Kurang Efektif & 25 & 55,6 & 20 & 44,4 & 45 & 100 & $3,1-20,5$ & 0,000 \\
\hline Jumlah & 33 & 31,7 & 71 & 68,3 & 104 & 100 & & \\
\hline Pengambilan & & & & & & & & \\
\hline Keputusan : & & & & & & & & \\
\hline - Tepat & 21 & 25,6 & 61 & 74,4 & 82 & 100 & 3,486 & 0,020 \\
\hline - Kurang Tepat & 12 & 54,5 & 10 & 45,5 & 22 & 100 & $1,3-9,2$ & \\
\hline Jumlah & 33 & 31,7 & 71 & 68,3 & 104 & 100 & & \\
\hline $\begin{array}{l}\text { Sosialisasi Karir \& } \\
\text { Jenjang Karir : }\end{array}$ & & & & & & & & \\
\hline - Jelas & 22 & 23,9 & 70 & 76,1 & 92 & 100 & 35,00 & 0,000 \\
\hline - Kurang Jelas & 11 & 91,7 & 1 & 8,3 & 12 & 100 & $4,2-286,5$ & \\
\hline Jumlah & 33 & 31,7 & 71 & 68,3 & 104 & 100 & & \\
\hline
\end{tabular}


Selain itu juga didapatkan ada perbedaan proporsi sosialisasi karir dan jenjang karir antara struktur organisasi pada pendekatan sentralisasi dengan pendekatan desentralisasi $(\mathrm{p}=0,020 ; \mathrm{OR}=2,556$, $\alpha=0,05)$. Struktur dengan pendekatan desentralisasi mempunyai peluang 2,55 kali untuk memperjelas sosialisasi karir dan jenjang karir dibandingkan dengan struktur dengan pendekatan sentralisasi.

Hasil analisis statistik menunjukkan bahwa tidak ada perbedaan proporsi efektivitas organisasi antara struktur organisasi pada pendekatan sentralisasi dengan desentralisasi ( $p=0,267, \alpha=0,05)$ (tabel 6). Sosialisasi karir dan jenjang karir merupakan variabel yang paling besar pengaruhnya terhadap efektivitas organisasi pada pendekatan sentralisasi (tabel 7).
Pengambilan Keputusan merupakan variabel yang paling besar pengaruhnya terhadap Efektivitas Organisasi Desentralisasi setelah dikontrol dengan interaksi antara komunikasi dengan sosialisasi karir dan jenjang karir (lihat tabel 8).

\section{Pembahasan}

Hasil penelitian pada variabel komunikasi pada pendekatan sentralisasi diperoleh bahwa sebagian besar responden mengatakan bahwa komunikasi kurang efektif. Namun, pada pendekatan desentralisasi, sebagian besar responden mengatakan bahwa komunikasi sudah efektif. Berdasarkan teori seharusnya memang ada perbedaan komunikasi pada kedua pendekatan (Gillies, 1994).

Tabel 4. Hubungan Proses Organisasi Dengan Efektivitas Organisasi pada Pendekatan Desentralisasi

\begin{tabular}{|c|c|c|c|c|c|c|c|c|}
\hline \multirow{3}{*}{ Proses Organisasi } & \multicolumn{4}{|c|}{ Efektivi tas Organisasi } & \multirow{2}{*}{\multicolumn{2}{|c|}{ Total }} & \multirow{3}{*}{$\begin{array}{c}\text { OR } \\
95 \% \mathrm{CI}\end{array}$} & \multirow{3}{*}{$\mathbf{p}$} \\
\hline & \multicolumn{2}{|c|}{ Efektif } & \multicolumn{2}{|c|}{ Kurang Efektif } & & & & \\
\hline & $\mathbf{N}$ & $\%$ & $\mathbf{N}$ & $\%$ & $\mathbf{N}$ & $\%$ & & \\
\hline \multicolumn{9}{|l|}{ Komunikasi : } \\
\hline - Efektif & 11 & 22 & 39 & 78 & 50 & 100 & 5,571 & \multirow{3}{*}{0,000} \\
\hline - Kurang Efekt if & 33 & 61,1 & 21 & 38,9 & 54 & 100 & $2,3-13,2$ & \\
\hline Jumlah & 44 & 42,3 & 60 & 57,7 & 104 & 100 & & \\
\hline \multicolumn{9}{|l|}{ Penga mbilan } \\
\hline Keputusan : & & & & & & & & \multirow{4}{*}{0,000} \\
\hline - Tepat & 13 & 21 & 49 & 79 & 62 & 100 & 10,622 & \\
\hline - Kurang Tepat & 31 & 73,8 & 22 & 26,2 & 42 & 100 & $4,2-26,6$ & \\
\hline Jumlah & 44 & 42,3 & 60 & 57,7 & 104 & 100 & & \\
\hline \multicolumn{9}{|l|}{$\begin{array}{l}\text { Sosiali sasi Karir \& } \\
\text { Jenjang Karir : }\end{array}$} \\
\hline - Jelas & 20 & 76,9 & 6 & 23,1 & 26 & 100 & 7,500 & \multirow[t]{3}{*}{0,000} \\
\hline - Kurang Jelas & 24 & 30,8 & 54 & 69,2 & 78 & 100 & $2,7-21,0$ & \\
\hline Jumlah & 60 & 57,7 & 44 & 42,3 & 104 & 100 & & \\
\hline
\end{tabular}

Pada pendekatan sentralisasi, seorang kepala bidang keperawatan saat itu hanya menjadi penghubung antara administrator dengan unit-unit pelayanan keperawatan. Konsekuensi dari situasi ini fungsi manajemen midle manager yang sangat memerlukan keterampilan komunikasi seorang manajer menjadi terbaikan. Pada pendekatan desentralisasi, arah komunikasi yang cenderung terjadi adalah komunikasi 2 (dua) arah sehingga lebih efektif.

Hasil penelitian pada variabel pengambilan keputusan, menunjukkan sebagian besar responden mengatakan pengambilan keputusan kurang tepat baik pada pendekatan sentralisasi maupun pada pendekatan desentralisasi. Hal ini dapat terjadi karena organisasi yang tersentralisasi pengambilan keputusan hanya dilakukan oleh beberapa manajer pada tingkat atas dan besarnya struktur organisasi yang dimiliki oleh RSUD dapat menyebabkan semakin kompleksnya permasalahan yang dihadapi.

Pada pendekatan desentralisasi, hasil penelitian ini menjukkan bahwa pengambilan keputusan pada struktur organisasi dengan pendekatan desentralisasi masih kurang tepat. Kurang tepatnya pengambilan keputusan dipersepsikan oleh perawat pelaksana dapat disebabkan oleh kurang tepatnya manajer tingkat pertama dan tingkat menengah dalam mengambil keputusan karena kurang memahami fungsi dan perannya sebagai seorang manajer. Hal ini terkait dengan masih kurangnya kualitas SDM manajerial di pelayanan keperawatan. 
Tabel 5. Uji Beda Proses Organisasi pada Pendekatan Sentralisasi dan Desentralisasi

\begin{tabular}{|c|c|c|c|c|c|c|c|c|}
\hline \multirow{2}{*}{ Proses Organisasi } & \multicolumn{2}{|c|}{ Sentralisasi } & \multicolumn{2}{|c|}{ Desentralisasi } & \multicolumn{2}{|c|}{ Total } & \multirow{2}{*}{$\begin{array}{c}\text { OR } \\
(95 \% \mathrm{CI})\end{array}$} & \multirow{2}{*}{$\mathbf{p}$} \\
\hline & $\mathbf{N}$ & $\%$ & $\mathbf{N}$ & $\%$ & $\mathbf{N}$ & $\%$ & & \\
\hline $\begin{array}{l}\text { Komunikasi : } \\
\text { - Efektif } \\
\text { - Kurang Efektif }\end{array}$ & $\begin{array}{l}45 \\
59\end{array}$ & $\begin{array}{l}43,3 \\
56,7\end{array}$ & $\begin{array}{l}54 \\
50\end{array}$ & $\begin{array}{l}51,9 \\
48,1\end{array}$ & $\begin{array}{c}99 \\
109\end{array}$ & $\begin{array}{l}47,6 \\
52,4\end{array}$ & $\begin{array}{c}1,416 \\
0,8-2,4\end{array}$ & 0,267 \\
\hline Jumlah & 104 & 100 & 104 & 100 & 208 & 100 & & \\
\hline $\begin{array}{l}\text { Pengambilan } \\
\text { Keputusan : } \\
\text { - Tepat } \\
\text { - Kurang Tepat }\end{array}$ & $\begin{array}{l}22 \\
82\end{array}$ & $\begin{array}{l}21,2 \\
78,8\end{array}$ & $\begin{array}{l}42 \\
62\end{array}$ & $\begin{array}{l}40,4 \\
59,6\end{array}$ & $\begin{array}{c}64 \\
144\end{array}$ & $\begin{array}{l}30,8 \\
69,2\end{array}$ & $\begin{array}{c}2,525 \\
1,3-4,6\end{array}$ & 0,004 \\
\hline Jumlah & 104 & 100 & 104 & 100 & 208 & 100 & & \\
\hline $\begin{array}{l}\text { Sosialisasi Karir dan } \\
\text { Jenjang Karir : } \\
\text { - Jelas } \\
\text { - Kurang Jelas } \\
\quad \text { Jumlah }\end{array}$ & $\begin{array}{c}12 \\
92 \\
104\end{array}$ & $\begin{array}{l}11,5 \\
88,5\end{array}$ & $\begin{array}{l}26 \\
78\end{array}$ & $\begin{array}{c}25 \\
75 \\
100\end{array}$ & $\begin{array}{c}38 \\
170\end{array}$ & $\begin{array}{l}18,3 \\
81,7\end{array}$ & $\begin{array}{c}2,556 \\
1,2-5,4\end{array}$ & 0,020 \\
\hline
\end{tabular}

Hasil penelitian pada variabel sosialisasi karir dan jenjang karir, pendekatan sentralisasi maupun desentralisasi memperlihatkan sebagian besar responden mengatakan sosialisasi karir dan jenjang karir kurang jelas. Pada kedua pendekatan, hasil tersebut dapat terjadi karena kurang jelas sosialisasi karir dan jenjang karir pada struktur organisasi lama (sentralisasi) dapat merupakan akibat dari kurang adekuatnya pelaksanaan tanggung jawab dan fungsi pengembangan karir oleh pihak manajemen.

Hasil penelitian efektivitas organisasi pada pendekatan sentralisasi maupun desentralisasi menunjukkan sebagian besar responden mengatakan bahwa organisasi RS masih kurang efektif. Berdasarkan analisis peneliti, yang menjadi kendala pada saat itu adalah pengorganisasian pelayanan yang belum optimal, karena pada saat itu Kepala Bidang Keperawatan pernah dipimpin oleh seseorang yang bukan dari profesi keperawatan dan ketika posisi tersebut diberikan kepada seorang perawat, namun masih kurang memahami peran dan fungsi bidang keperawatan, sehingga efektivitas organisasi pelayanan keperawatan juga tidak terjadi.
Pada pendekatan desentralisasi, ketidakefektifan organisasi dapat disebabkan karena saat ini Kepala Bidang Pelayanan yang secara struktural membawahi pelayanan keperawatan dijabat oleh seseorang yang bukan dari profesi perawat. Disisi lain, masing-masing sub bidang dipimpin oleh perawat dengan latar belakang D-III keperawatan dan belum dapat menjalankan peran dan fungsinya secara optimal.

Hasil penelitian proses organisasi pada pendekatan sentralisasi dan desentralisasi menunjukkan hasil yang hampir sama. Proses organisasi pada pendekatan sentralisasi menunjukkan komunikasi yang kurang efektif, pengambilan keputusan yang kurang tepat serta sosialisasi karir dan jenjang karir yang kurang jelas, sehingga menghasilkan organisasi yang kurang efektif pula. Pada pendekatan desentralisasi menunjukkan pengambilan keputusan yang kurang tepat dan faktor sosialisasi karir dan jenjang karir yang kurang jelas. Walaupun komunikasi sudah efektif, tetapi karena dua faktor lain masih kurang sehingga tetap dapat menyebabkan organisasi yang kurang efektif pula.

Tabel 6. Uji Beda Efektivitas Organisasi pada Pendekatan Sentralisasi dan Desentralisasi

\begin{tabular}{|c|c|c|c|c|c|c|c|c|}
\hline \multirow{2}{*}{$\begin{array}{l}\text { Efektivitas } \\
\text { Organisasi }\end{array}$} & \multicolumn{2}{|c|}{ Sentralisasi } & \multicolumn{2}{|c|}{ Desen tralisasi } & \multicolumn{2}{|c|}{ Total } & \multirow{2}{*}{$\begin{array}{c}\text { OR } \\
(95 \% \mathrm{CI}) \\
\end{array}$} & \multirow{2}{*}{$\mathbf{p}$} \\
\hline & $\mathbf{N}$ & $\%$ & $\mathbf{N}$ & $\%$ & $\mathbf{N}$ & $\%$ & & \\
\hline Efektif & 33 & 31,7 & 44 & 42,3 & 77 & 37 & & \\
\hline Kurang Efektif & 71 & 68,3 & 60 & 57,7 & 131 & 63 & $\begin{array}{l}1,578 \\
0\end{array}$ & 0,267 \\
\hline Jumlah & 104 & 100 & 104 & 100 & 208 & 100 & $0,9-2,8$ & \\
\hline
\end{tabular}


Hasil penelitian memperlihatkan ada hubungan yang signifikan antara komunikasi dengan efektivitas organisasi pada pendekatan sentralisasi dan desentralisasi. Dapat disimpulkan bahwa semakin efektif komunikasi di dalam organisasi, maka semakin efektif pula organisasi tersebut.

Pada penelitian juga diperoleh hasil bahwa bahwa ada hubungan yang signifikan antara pengambilan keputusan dengan efektivitas organisasi pada pendekatan sentralisasi dan desentralisasi. Dapat disimpulkan bahwa semakin tepat pengambilan keputusan di dalam organisasi, maka semakin efektif pula organisasi tersebut.

Tabel 7. Hasil Analisis Multivariat Regresi Logistik antara Variabel Komunikasi, Sosialisasi Karir dan Jenjang Karir dengan Efektivitas Organisasi pada Pendekatan Sentralisasi

\begin{tabular}{lcccc}
\hline \multirow{1}{*}{ Variabel } & Sig. & OR/ & \multicolumn{2}{c}{$95.0 \%$ C.I. for } \\
& & Exp(B) & EXP(B) \\
Lower & Upper \\
\hline Komunikasi & 0,001 & 5,329 & 1,940 & 14,634 \\
$\begin{array}{l}\text { Sosialisasi Karir } \\
\text { dan Jenjang Karir }\end{array}$ & 0,008 & 18,512 & 2,126 & 161,196 \\
\hline
\end{tabular}

Selanjutnya, hasil penelitian juga menunjukkan ada hubungan yang signifikan antara sosialisasi karir dan jenjang karir dengan efektivitas organisasi pada pendekatan sentralisasi dan desentralisasi. Dapat disimpulkan bahwa semakin jelas sosialisasi karir dan jenjang karir di dalam organisasi, maka semakin efektif pula organisasi tersebut. Dari hasil analisis multivariat dengan uji regresi logistik prediksi dapat disimpulkan bahwa sosialisasi karir dan jenjang karir merupakan yang paling besar pengaruhnya terhadap efektivitas organisasi pada pendekatan sentralisasi.

Analisis multivariat juga menghasilkan kesimpulan bahwa pengambilan keputusan merupakan yang paling besar pengaruhnya terhadap efektivitas organisasi pada pendekatan desentralisasi setelah dikontrol dengan interaksi antara komunikasi dengan sosialiasi karir dan jenjang karir. Hasil ini sesuai karena proses organisasi melibatkan tiga proses perilaku yang berkontribusi dalam kinerja dan efektivitas organisasi, yaitu komunikasi, pengambilan keputusan dan sosialisasi karir serta pengembangan karir.

Hasil penelitian pada struktur organisasi dengan pendekatan desentralisasi menunjukkan pengambilan keputusan sudah tepat. Namun, hal tersebut tidak berdiri sendiri dalam menghasilkan efektivitas organisasi, tetapi juga dipengaruhi oleh hubungan antara komunikasi dan sosialisasi karir dan jenjang karir.

\section{Kesimpulan}

Penelitian ini menjawab hipotesis adanya hubungan antara proses organisasi dengan efektivitas organisasi, dan pengambilan keputusan paling besar pengaruhnya setelah dikontrol interaksi antara komunikasi dan sosialisasi karir dan jenjang karir. Hasil penelitian juga menunjukkan bahwa tidak ada perbedaan antara komunikasi dan efektivitas organisasi, namun ditemukan ada perbedaan pengambilan keputusan serta sosialisasi karir dan jenjang karir pada pendekatan sentralisasi dan desentralisasi.

Hasil penelitian ini diharapkan dapat digunakan oleh pihak manajemen untuk mengembangkan SOP (Standard Operational Procedure) yang dapat dijadikan instrumen atau metode dalam pengambilan keputusan, menyusun program sosialisasi karir dan sistem jenjang karir yang transparan dan objektif, melakukan evaluasi terhadap kinerja atau efektivitas rumah sakit secara berkala dengan mengembangkan instrumen yang sesuai kebutuhan rumah sakit.

Tabel 8. Hasil Analisis Multivariat Regresi Logistik antara Komunikasi, Pengambilan Keputusan, Sosialisasi Karir dan Jenjang Karir Terhadap Efektivitas Organisasi pada Pendekatan Desentralisasi

\begin{tabular}{lcccc}
\hline \multicolumn{1}{c}{ Variabel } & \multirow{2}{*}{ Sig. } & \multicolumn{2}{c}{ OR / } & \multicolumn{2}{c}{ 95.0\% C.I. for EXP (B) } \\
& & Exp (B) & Low er & Upper \\
\hline Komunikasi & 0,001 & 10,347 & 2,739 & 39,087 \\
Pengambilan Keputusan & 0,000 & 11,269 & 3,110 & 40,840 \\
Sosialisasi Karir dan Jenjang Karir & 0,045 & 8,828 & 1,050 & 74,243 \\
Komunikasi*Sosialisasi Karir dan & 0,057 & 0,71 & 0,005 & 1,087 \\
Jenjang Karir & & & & \\
\hline
\end{tabular}


Selanjutnya, pihak manajemen diharapkan dapat melakukan evaluasi terhadap struktur organisasi rumah sakit yang ada saat ini (MS, TN, KN).

\section{Referensi}

Beyers, M. (1999). About working without a nursing departement. Diperoleh dari http:// www.nursingmanagement.com.

Gibson, J.L., Ivancevich, J.M., \& Donelly, J.H. (1996). Organisasi: Perilaku, struktur, dan proses (Jilid 1) (Edisi ke-8). Jakarta: Binarupa Aksara.

Gibson, J.L., Ivancevich, J.M., \& Donelly, J.H. (1996). Organisasi: Perilaku, struktur, dan proses (Jilid 2) (Edisi ke-8). Jakarta: Binarupa Aksara.

Gillies, D.A. (1994). Nursing management: A system approach (3rd Edition). Philadelphia: W.B. Saunders.

Ilyas, Y. (2004). Perencanaan SDM rumah sakit: Teori, metoda dan formula. Depok: Pusat Kajian Ekonomi Kesehatan FKM UI.
Marquis, B.L. \& Huston, C.J. (2006). Leadership roles and management function in nursing: Theory and application (5th Edition). Philadelphia: Lippincott Wlliams \& Wilkins.

Muray, M.E.G., DiCroce, H.R. (1997). Leadership and management in nursing. Stamford, Connecticut: Appleton \& Lange.

Organizational effectivenes. (2002). Governance West, Inc. Diperoleh dari http://www. governancewest.com.

Robbins, S.P. (2002). Prinsip-prinsip perilaku organisasi (Edisi Kelima) (Alih bahasa: Halida \& Dewi Sartika). Jakarta: Erlangga.

Schmid, H. (2002). Relationship between organizational properties and organizational effectiveness in three types of nonprofit human services organizations. Nursing \& Allied Health Source. Diperoleh dari http://www.proquest.com/pqdauto/ proquest.

Winardi, J., (2004). Manajemen perilaku organisasi. Jakarta: Prenada Media.

Kita bisa membiarkan keadaan mengatur kita, atau kita dapat mengambil alih dan menguasai hidup kita dari dalam.

- Earl Nightingale -

Jangan mencari kawan yang membuat Anda merasa nyaman, tetapi carilah kawan yang memaksa Anda terus berkembang

- Thomas J.Watson -

Tinggalkanlah kesenangan yang menghalangi pencapaian

kecemerlangan hidup yang diidamkan. Dan berhati-hatilah, karena beberapa kesenangan adalah cara gembira menuju kegagalan.

- Mario Teguh -

Imajinasi anda adalah prapertunjukan akan daya tarik kehidupan yang akan datang.

- Albert Einstein - 